\title{
Advancing food democracy: The potential and limits of food policy positions in local government
}

\author{
Erika Berglund ${ }^{a *}$ and Neva Hassanein ${ }^{b}$ \\ University of Montana \\ Paul Lachapelle ${ }^{c}$ \\ Montana State University \\ Caroline Stephens ${ }^{\mathrm{d}}$ \\ University of Montana
}

Submitted January 31, 2021 / Revised March 14 and May 29, 2021 / Accepted June 1, 2021 /

Published online October 22, 2021

Citation: Berglund, E., Hassanein, N., Lachapelle, P., \& Stephens, C (2021). Advancing food democracy:

The potential and limits of food policy positions in local government. Journal of Agriculture, Food Systems,

and Community Development, 11(1), 81-98. https://doi.org/10.5304/jafscd.2021.111.002

Copyright (C) 2021 by the Authors. Published by the Lyson Center for Civic Agriculture and Food Systems. Open access under CC-BY license.

\begin{abstract}
For several decades, food policy councils (FPCs) have led the effort to place food on local government policy agendas. While FPCs are making progress in supporting local food systems, they also

a* Corresponding author: Erika Berglund, M.S., Environmental Studies Program, University of Montana.

Ms. Berglund is now at JG Research and Evaluation; 2103

Bridger Drive, Suite 1; Bozeman, MT 59715 USA; +1-805-

708-8864; erikafairb@gmail.com

b Neva Hassanein, Professor, Environmental Studies Program, University of Montana, Jeannette Rankin Hall 106A, Missoula, MT 59812 USA; neva.hassanein@mso.umt.edu

c Paul Lachapelle, Professor, Department of Political Science, Montana State University, P.O. Box 172240, Bozeman, MT 59717 USA; paul.lachapelle@montana.edu

${ }^{\mathrm{d}}$ Caroline Stephens, Lecturer, Environmental Studies Program, University of Montana, Jeannette Rankin Hall 106A, Missoula, MT 59812 USA; caroline.stephens@mso.umt.edu
\end{abstract}

face institutional and organizational challenges. In recent years, a handful of cities and counties have endeavored to further food system reform with the establishment of full-time government staff positions focused on food policy. As of spring 2020, there were 19 confirmed food policy positions housed in local governments across the United States. While there is considerable literature on FPCs, little research has been published regarding food policy staffing in local governments.

\section{Funding Disclosure}

The authors are grateful for the support of the University of Montana BRIDGES program, funded by National Science Foundation Grant No. DGE-1633831, as well as funding provided to the first author from the University of Montana Graduate School, Environmental Studies Program, and Brainerd Foundation.

\section{Author Note}

The original research for this article was conducted as part of the first author's graduate student professional paper. 
Accordingly, this study uses original in-depth interviews with 11 individuals in municipal or county food policy positions to understand the purpose and function of governmental food policy staff positions and their impact on local food systems. Our findings suggest that these positions help to coordinate and nurture local food programs and policies and have the potential to facilitate meaningful participation of individuals and groups in the community in food system reform. We discuss the potential benefits and challenges for governmental food policy positions to support food democracy, and provide the following recommendations for communities interested in establishing or strengthening similar positions: (1) identify and coordinate existing opportunities and assets, (2) foster and maintain leadership support, (3) root the work in community, (4) connect with other food policy professionals, and (5) develop a food system vision.

\section{Keywords}

Food Policy, Food Democracy, Coordination, Local Government, Food System, Food Policy Council

\section{Introduction}

Over the last several decades, numerous scholars, community development practitioners, and activists have critiqued the dominant, industrial food system, in part because of the extraordinary levels of economic and political power held by transnational agri-food firms. In particular, the concentration of economic power among agri-food firms means that a small number of firms have gained extensive control over the shape and development of the agri-food system at nearly every level, from seeds and inputs, to processing, to retail (Hendrickson et al., 2017; Lang et al., 2009). This oligopolistic power structure has produced a globalized food system that exacts an extraordinary toll on the living and working conditions of farmers and farm laborers, the biodiversity and health of ecosystems, the rights and well-being of marginalized communities, and the health of consumers. In response, calls for more democratic food systems have amplified concerns about the need for sustainability and equity in the dominant food system.
Food democracy envisions individuals and communities as vital, active participants in shaping more just, equitable, and community-based food systems (Hassanein, 2003; Sieveking, 2019). One manifestation of the potential for food democracy is the ever-expanding network of food policy councils (FPCs), which have been established in localities throughout the United States and the world (Johns Hopkins University Center for a Livable Future, n.d.). For several decades, FPCs have emerged as desired forums for civic participation in the food system, and laid substantial groundwork in placing food on local government policy agendas where it once was notably absent (Feenstra, 1997; Muller et al., 2009; Pothukuchi \& Kaufman, 1999;). In 2018, 283 FPCs in the U.S. were verified as either active, in development, or in transition (Santo et al., 2021). Many FPCs serve as vital institutions for fostering food democracy and advising local governments in their efforts to create vibrant, resilient, and equitable local food systems (Bassarab et al., 2019; Hassanein, 2003; Sieveking, 2019). FPCs also have the potential to promote many of the basic tenets of community development, including encouraging local self-reliance, building resiliency, supporting equity and justice, and enhancing social capital, to name but a few (Christensen \& Phillips, 2017; Lamie \& Deller, 2017). Yet, despite their fundamental role in food system reform and food democracy, FPCs face limitations in their capacity and resources. For example, the majority of FPCs primarily rely on volunteer membership, and only 36\% $(n=198)$ of those who responded to the 2020 Food Policy Networks survey report having paid staff, which may limit the depth and breadth of their work (Santo et al., 2021).

In many cases, a lack of financial and personnel resources causes FPCS to focus more heavily on programs, rather than policy (Gupta et al., 2018; Scherb et al., 2012; Schiff, 2008). According to interviews conducted by Schiff (2008), some FPCs expressed that having a programmatic focus allows them to engage in the hands-on implementation of food policy rather than getting bogged down in the bureaucracy and political messiness of researching, developing, and recommending policy. While FPCs may be more experienced and efficient in develop- 
ing and supporting food-related programs, this lack of focus on policy suggests that there remains a gap in the development stage of food policy for many communities. This gap points to earlier scholarship on community food policy and planning by Pothukuchi and Kaufman (1999), which identified FPCs as one of multiple approaches to pursuing local food policy initiatives. Communities, they argued, may also find opportunities to create comprehensive food system plans and policies through municipal departments of food or by integrating food policy into existing planning agencies. Rather than relying on one policy model, communities may find food systems work can be amplified and strengthened through an integrated and multifaceted approach.

Few studies of the role of government actors or civil servants in facilitating food democracy exist in the literature (van de Griend et al., 2019). Yet, some local governments have recently established staff positions centered on local food policy or food systems (Hatfield, 2012; Santo et al., 2014). The number of city and county food policy staff positions in the U.S. has fluctuated, in part because food policy and food systems planning are novel additions to local government agendas. Therefore, there is little precedent for longitudinal studies or determining best practices (Hatfield, 2012). The overall trend, however, is one of growth in numbers, having reached 19 confirmed positions in the U.S. by 2020. Nearly all of these positions were established in the previous five years (as detailed in our findings below).

While local governments continue to establish these positions, there is little scholarship regarding their genesis, development, and impacts on food democracy. In an important recent addition to the literature, however, van de Griend et al. (2019) conducted an ethnographic study in the Dutch municipality of Ede that specifically explored how government actors working on an urban food policy shaped the conditions for different types of participation among non-governmental organizations. Evaluating civic participation as a key dimension of food democracy and a core strategy for citizens to shape their community's food system, they found that food democracy can be enhanced and made more inclusive when a municipality commits to achieving a holistic food policy and creates spaces for civic participation. Moreover, van de Griend et al. (2019) argue for balancing a strong leadership role in local government with a more open and responsive approach toward nongovernmental organizations. Such a balance, they contend, will not only facilitate movement toward achieving food policy objectives, but also enhance food democracy through meaningful civic participation and collaborative action.

In order to add to the emerging literature on the role of government actors in food democracy, this article presents the results of research on these relatively new food policy positions in local governments in the U.S., as well as the benefits, challenges, and outcomes of their work. Our specific research questions are: (1) Based on the experiences of communities with food policy staff positions, what opportunities do food policy staff positions provide local governments in terms of advancing the creation of a more healthy, sustainable, and equitable food system? (2) What limitations or challenges do these staff encounter as they try to achieve specific outcomes? (3) How might these positions be helping to advance food democracy? Similar to Sieveking's (2019) evaluation of FPCs in Germany, we operationalize the concept of food democracy using Hassanein's (2008) framework as a means for analyzing governmental food policy positions as tools for food democracy. In particular, we consider the following key dimensions of food democracy:

(1) Collaborating toward food system sustainability;

(2) Becoming knowledgeable about food and the food system;

(3) Sharing ideas about the food system with others;

(4) Developing efficacy concerning food and the food system; and

(5) Acquiring an orientation toward the community good.

To address our research questions, we carried out and thematically analyzed original, in-depth interviews with 11 individuals in municipal or county food policy staff positions. Based on this 
thematic analysis, we describe the relevance of governmental food policy staff positions to U.S. communities and reflect upon the potential for such positions to support the principles of food democracy in community food systems. We then provide recommendations for communities interested in establishing food policy positions in local government. Finally, we discuss opportunities for future research of governmental food policy positions as emergent models of food democracy.

\section{Methods}

In order to generate the sample for this study, we endeavored to identify and verify all active food policy staff positions in city or county governments throughout the U.S. This process began with referencing Hatfield's (2012) study, and crossreferencing that information with resources such as the Food Policy Networks directory (Johns Hopkins Center for a Livable Future, n.d.), local government online resources, and the U.S. Conference of Mayors Food Policy Task Force (United States Conference of Mayors, n.d.). The preliminary list of food policy staff positions was then reviewed and updated by the senior program officer at the Johns Hopkins University Center for a Livable Future (K. Bassarab, personal communication, January 28, 2020).

The verified list includes 19 municipal or county governmental food policy staff positions as of 2020. From this list, 11 individuals were interviewed using a semistructured format in spring 2020. While individuals in all 19 positions were invited to participate, several did not respond and a handful were unable to participate within the time constraints of the project. Thus, our sample represents $58 \%$ of all known positions at the time. Table 1 shows a list of interview participants. Participant identity was not made confidential because participants work in local government and their information is publicly available; furthermore, the authors felt that their identity and location would provide a valuable resource for collaboration and networking opportunities.

In general, interview questions addressed the participants' professional background, the history and responsibilities of their position, and their experiences working at the job. The interview guide is in the Appendix. Audio from each interview was recorded, transcribed verbatim, and analyzed using thematic content analysis (HesseBiber, 2017). A comprehensive description of the methods used is detailed in Berglund (2020).

\section{Descriptive Findings}

The findings presented in this section describe the themes and topics most frequently discussed among the 11 interview participants. The central themes that emerged include organizational structure, benefits of the position, challenges of the position, lessons learned, and recommendations for establishing a food policy position. Based on these findings, we then analyzed the potential and limitations of food policy positions to support food democracy using the key dimensions of food democracy introduced above and described by Hassanein (2008).

\section{Organizational Structure}

Governmental food policy staff are positioned in local government in a myriad of ways. For example, we note that positions are often housed in a variety of departments, including sustainability, economic development, public health, the mayor's office, and county extension. Among the 11 individuals interviewed, each position has a different title, but all have a food systems or food policy focus and serve in a leadership or advisory capacity. As of April 2020, all these positions are one full-time equivalent (1 FTE). Seven serve as the sole staff person working on food systems in their government. At the same time, all but one of the communities represented in this research have an active food policy council or board, which the respective food policy staff is tasked with supporting (Lexington, Kentucky, does not have a council). Two positions, the Columbus local food systems strategies coordinator and Franklin County food systems planner, support the same food board and local food council, because the city of Columbus is located within Franklin County.

In general, these 11 positions were established as the result of collaborative action and advocacy by community leaders and elected officials, such as mayors, local FPCs, and/or leadership in governmental departments. The motivations behind 
Table 1. Description of Eleven Positions and the Respective Food Policy Council as of May 2020

\begin{tabular}{|c|c|c|c|c|c|c|c|c|c|c|c|}
\hline City or County & Name of Position & $\begin{array}{c}\text { Year } \\
\text { Established }\end{array}$ & $\begin{array}{l}\text { Position } \\
\text { Location }\end{array}$ & Position Funding & $\begin{array}{l}\text { Individual } \\
\text { in Position }\end{array}$ & $\begin{array}{l}\text { Years in } \\
\text { Position }\end{array}$ & $\begin{array}{l}\text { Addi- } \\
\text { tional } \\
\text { Staff }\end{array}$ & $\begin{array}{l}\text { Food Policy } \\
\text { Council }\end{array}$ & $\begin{array}{c}\text { Year FPC } \\
\text { Established }\end{array}$ & Structure & Members \\
\hline Austin, TX & $\begin{array}{l}\text { Food Policy } \\
\text { Manager }\end{array}$ & 2014 & $\begin{array}{l}\text { Office of } \\
\text { Sustainabiity }\end{array}$ & City general fund & Edwin Marty & 6 years & 1.5 & $\begin{array}{l}\text { Austin-Travis } \\
\text { County Food } \\
\text { Board }\end{array}$ & 2008 & $\begin{array}{l}\text { Govern- } \\
\text { mental }\end{array}$ & 13 \\
\hline $\begin{array}{l}\text { Columbus, } \\
\mathrm{OH}\end{array}$ & $\begin{array}{l}\text { Local Food } \\
\text { Systems } \\
\text { Strategies } \\
\text { Coordinator }\end{array}$ & 2015 & $\begin{array}{l}\text { Public Health } \\
\text { Department }\end{array}$ & $\begin{array}{l}\text { Originally funded } \\
\text { through temporary } \\
\text { funds (i.e. grants, } \\
\text { foundations, inno- } \\
\text { vation fund); now } \\
\text { city general fund }\end{array}$ & $\begin{array}{l}\text { Cheryl L. } \\
\text { Graffagnino }\end{array}$ & 5 years & 1 & $\begin{array}{l}\text { Columbus- } \\
\text { Franklin County } \\
\text { Local Food } \\
\text { Board; Franklin } \\
\text { County Local } \\
\text { Food Council }\end{array}$ & $\begin{array}{l}2016 \\
2013\end{array}$ & $\begin{array}{l}\text { Govern- } \\
\text { mental; } \\
\text { nonprofit }\end{array}$ & $12 ; 10$ \\
\hline Denver, CO & $\begin{array}{l}\text { Food Systems } \\
\text { Administrator }\end{array}$ & 2015 & $\begin{array}{l}\text { Department of } \\
\text { Public Health } \\
\text { and } \\
\text { Environment }\end{array}$ & $\begin{array}{l}\text { Originally funded } \\
\text { through temporary } \\
\text { funds (i.e. grants, } \\
\text { foundations, inno- } \\
\text { vation fund); now } \\
\text { city general fund }\end{array}$ & $\begin{array}{l}\text { Laine } \\
\text { Cidlowski }\end{array}$ & 3 years & 5 & $\begin{array}{l}\text { Denver } \\
\text { Sustainable } \\
\text { Food Policy } \\
\text { Council }\end{array}$ & 2010 & $\begin{array}{l}\text { Govern- } \\
\text { mental }\end{array}$ & Varies \\
\hline $\begin{array}{l}\text { Indianapolis, } \\
\text { IN }\end{array}$ & $\begin{array}{l}\text { Food Policy and } \\
\text { Program } \\
\text { Coordinator }\end{array}$ & 2016 & $\begin{array}{l}\text { Office of Public } \\
\text { Health and } \\
\text { Safety }\end{array}$ & $\begin{array}{l}\text { City-county council } \\
\text { budget }\end{array}$ & $\begin{array}{l}\text { Milele } \\
\text { Kennedy }\end{array}$ & $\begin{array}{l}1 \text { year } \\
\text { or less }\end{array}$ & None & $\begin{array}{l}\text { Indy Food } \\
\text { Council }\end{array}$ & 2014 & $\begin{array}{l}\text { Govern- } \\
\text { mental }\end{array}$ & Varies \\
\hline $\begin{array}{l}\text { Lexington, } \\
\text { KY }\end{array}$ & $\begin{array}{l}\text { Director of Local } \\
\text { Food and } \\
\text { Agricultural } \\
\text { Development }\end{array}$ & 2014 & $\begin{array}{l}\text { Mayor's Office } \\
\text { of Economic } \\
\text { Development }\end{array}$ & $\begin{array}{l}\text { Originally funded } \\
\text { through temporary } \\
\text { funds (i.e. grants, } \\
\text { foundations, inno- } \\
\text { vation fund); now } \\
\text { city general fund }\end{array}$ & $\begin{array}{l}\text { Ashton } \\
\text { Potter-Wright }\end{array}$ & 6 years & None & None & N/A & N/A & N/A \\
\hline $\begin{array}{l}\text { Madison, } \\
\text { WI }\end{array}$ & $\begin{array}{l}\text { Food Policy } \\
\text { Director }\end{array}$ & $\begin{array}{c}2016 \\
(2012-16 \\
\text { was Food } \\
\text { and Alcohol } \\
\text { Policy } \\
\text { Coordinator) }\end{array}$ & Mayor's Office & City general fund & $\begin{array}{l}\text { George } \\
\text { Reistad }\end{array}$ & 4 years & None & $\begin{array}{l}\text { Madison Food } \\
\text { Policy Council }\end{array}$ & 2012 & $\begin{array}{l}\text { Govern- } \\
\text { mental }\end{array}$ & 23 \\
\hline $\begin{array}{l}\text { Minneapolis, } \\
\text { MN }\end{array}$ & $\begin{array}{l}\text { Local Food Policy } \\
\text { Coordinator }\end{array}$ & 2014 & $\begin{array}{l}\text { City } \\
\text { Coordinator's } \\
\text { Office, } \\
\text { Sustainability } \\
\text { Division }\end{array}$ & City general fund & $\begin{array}{l}\text { Tamara } \\
\text { Downs Schwei }\end{array}$ & 6 years & 2 & $\begin{array}{l}\text { Homegrown } \\
\text { Minneapolis } \\
\text { Food Council }\end{array}$ & 2011 & $\begin{array}{l}\text { Govern- } \\
\text { mental }\end{array}$ & 21 \\
\hline
\end{tabular}




\begin{tabular}{|c|c|c|c|c|c|c|c|c|c|c|c|}
\hline $\begin{array}{l}\text { City or } \\
\text { County }\end{array}$ & Name of Position & $\begin{array}{c}\text { Year } \\
\text { Established }\end{array}$ & $\begin{array}{l}\text { Position } \\
\text { Location }\end{array}$ & Position Funding & $\begin{array}{l}\text { Individual } \\
\text { in Position }\end{array}$ & $\begin{array}{l}\text { Years in } \\
\text { Position }\end{array}$ & $\begin{array}{l}\text { Addi- } \\
\text { tional } \\
\text { Staff }\end{array}$ & $\begin{array}{l}\text { Food Policy } \\
\text { Council }\end{array}$ & $\begin{array}{l}\text { Year FPC } \\
\text { Established }\end{array}$ & Structure & Members \\
\hline $\begin{array}{l}\text { Salt Lake } \\
\text { City, UT }\end{array}$ & $\begin{array}{l}\text { Food and Equity } \\
\text { Program } \\
\text { Manager }\end{array}$ & 2019 & $\begin{array}{l}\text { Sustainability } \\
\text { Department }\end{array}$ & $\begin{array}{l}\text { Originally funded } \\
\text { through temporary } \\
\text { funds (i.e. grants, } \\
\text { foundations, inno- } \\
\text { vation fund); now } \\
\text { city general fund }\end{array}$ & Supreet Gill & $\begin{array}{l}1 \text { year } \\
\text { or less }\end{array}$ & None & $\begin{array}{l}\text { Salt Lake City } \\
\text { Food Policy } \\
\text { Council }\end{array}$ & 2008 & $\begin{array}{l}\text { Govern- } \\
\text { mental }\end{array}$ & Up to 16 \\
\hline $\begin{array}{l}\text { Douglas } \\
\text { County, KS }\end{array}$ & $\begin{array}{l}\text { Sustainability and } \\
\text { Food Systems } \\
\text { Analyst }\end{array}$ & 2014 & $\begin{array}{l}\text { Sustainability } \\
\text { Department }\end{array}$ & $\begin{array}{l}\text { Originally funded } \\
\text { through temporary } \\
\text { funds (i.e. grants, } \\
\text { foundations, inno- } \\
\text { vation fund); now } \\
\text { county general fund }\end{array}$ & $\begin{array}{l}\text { Kim Criner } \\
\text { Ritchie }\end{array}$ & $\begin{array}{l}1 \text { year } \\
\text { or less }\end{array}$ & None & $\begin{array}{l}\text { Douglas County } \\
\text { Food Policy } \\
\text { Council }\end{array}$ & 2010 & $\begin{array}{l}\text { Govern- } \\
\text { mental }\end{array}$ & 16 \\
\hline $\begin{array}{l}\text { Franklin } \\
\text { County, } \mathrm{OH}\end{array}$ & $\begin{array}{l}\text { Food Systems } \\
\text { Planner }\end{array}$ & 2016 & $\begin{array}{l}\text { Economic } \\
\text { Development } \\
\text { and Planning } \\
\text { Department }\end{array}$ & County general fund & $\begin{array}{l}\text { Brian } \\
\text { Estabrook }\end{array}$ & 3 years & None & $\begin{array}{l}\text { Columbus- } \\
\text { Franklin County } \\
\text { Local Food } \\
\text { Board; Franklin } \\
\text { County Local } \\
\text { Food Council }\end{array}$ & $\begin{array}{l}2016 \\
2013\end{array}$ & $\begin{array}{l}\text { Govern- } \\
\text { mental; } \\
\text { nonprofit }\end{array}$ & $12 ; 10$ \\
\hline
\end{tabular}


creating these positions centered around (1) elevating the food system, (2) developing a holistic and coordinated approach to food system governance, and (3) addressing the community's persistent food-related issues.

The role played by these food policy staff is often complex and dynamic, as a result of the structure of the food system and of shifting community needs, priorities, and resources. The responsibilities and duties assigned to these positions are distinct in some instances, but generally fall into the following categories:

- Communication, coordination, and public relations,

- Policy development and implementation,

- Project development, support, and management, and/or

- Food systems analysis.

When asked about which areas of food policy they prioritize in their position, the majority of study participants identified (a) economic development, (b) healthy food access, (c) food waste reduction and recovery, and (d) food procurement. Several participants also mentioned food production, land use planning, and transportation. These priority areas were most frequently determined by existing plans and policy activity in local government. However, several participants also pointed to community input and FPC recommendations as influential determinants of priority areas. In many instances, participants described working on policies and programs that address multiple priorities at once, such as the city of Madison's Healthy Food Retail Access Program, which provides funding support to small, food retail businesses in areas lacking in healthy food access.

Several positions described their job and its priorities as constantly evolving over time. Although their job priorities can be categorized into tidy boxes, in reality, the complex work requires a "systems-thinking" approach that includes understanding various food system elements and their interconnections, scales, and feedback loops (Bassarab et al., 2019; Clancy, 2012; Palmer \& Santo, 2020). For example, the city of Austin faces urgent issues around affordable housing, healthy food access, and farmland preservation, and addressing one issue in isolation may undermine progress on another. As Austin's food policy manager, E. Marty, explained: "We really spent the last five years trying to unwind that very complex equation ... what I call a triangulation of quality of life, where we need to have dense, affordable housing located near good food retail in combination with access to multi-mobility transportation options." Similarly, Indianapolis's food policy and program coordinator strives to identify and address the root causes of poverty to more meaningfully address food insecurity at the city scale.

\section{Benefits of the Position}

In considering the value of their particular position and the role it plays for their community, participants mentioned a number of benefits, broadly grouped into four thematic categories: (1) coordination and collaboration, (2) food system leadership, (3) capacity building, and (4) systems thinking. The majority of participants spoke to benefits in all four categories, with coordination and collaboration benefits mentioned most frequently.

Coordination and collaboration. Seven participants described being a kind of point-person for food systems in government and the larger community_someone who fills a communication and coordination gap. B. Estabrook, food systems planner for Franklin County, $\mathrm{OH}$, explained:

The primary benefit is that there is someone within the county who is aware of all of this work happening across multiple different, siloed efforts and can understand and communicate across all those silos and coordinate work and make connections. A big, big, big, big part of our role with the local food team is coordination, collaboration, connection. And so, that can only be done if someone knows everything that's going on. So, a lot of the benefit is just having one sort of centralized hub where those things are known.

Leadership. Rather than addressing the food system in a patchwork fashion or with part-time 
staff, which is frequent in local government (Harper et al., 2009), these full-time policy staff are uniquely focused on the food system, affording them the opportunity to foster a leadership role. Along with coordination and expertise, interviewees described how they practice leadership, especially through outreach. Five participants expressed that they are able to facilitate and lead conversations around food in their community and beyond. In some places, the food policy positions now involve a greater supervisory role. In Denver, for example, the food systems administrator, L. Cidlowski, has been able to grow the city's local food team to include five full-time staffers, now one of the largest municipal food systems teams in the country.

Capacity Development. Perhaps one of the more obvious benefits of these positions is that they build capacity for food systems work through the dedication of time, resources, and personnel, which in turn expands local government's ability to engage in and support food-related policy and programs. As government staff, they have access to key stakeholders and information, and are often able to leverage resources for food policy initiatives. Several participants mentioned that working in a municipality or county allows them to explore opportunities and incubate new programs through funding opportunities and the development of strategic relationships between government and non-government actors. Furthermore, five participants described their work as an effort to elevate and sustain existing programs, and not to undermine or co-opt grassroots initiatives by connecting them with resources and expertise to which they otherwise may not have access.

Providing staffing for food policy councils has tradeoffs when it comes to organizational capacity building. Five of the ten participants who staff their council specifically mentioned positive outcomes in building the capacity of the group by providing a more direct connection to local government and dedicated staff time. For instance, the sustainability and food systems analyst for Douglas County has been able to build the FPC's capacity by applying for grants and recruiting new members. Two participants, however, expressed concerns that their role in the FPC could lead to a sense of complacency or disempowerment among the members. Similarly, Schiff (2008) and Bassarab et al. (2019) found that a strong tie to government can strengthen a FPC's credibility and access to resources, but can also undermine its autonomy.

Systems Thinking. An advantage of working in local government is the freedom to apply complex systems thinking. For example, the city of Austin's food policy manager explained:

One of the great things about working for municipal government ... we have a lot of leeway to say, hey, this is a really complicated issue and we're not seeing any good way to describe this. And we're going to keep working on this and we're going to keep talking about it and keep putting this all on the table.

Several participants reported that their position in government allows them to be both nimble and thoughtful - that is, able to dedicate time to understanding complex issues in order to build the best possible outcomes. Even in government, G. Reistad thinks that his position is among only a few in the city of Madison with the opportunity to look and work across departments, organizations, and the community to develop and implement more integrated solutions. Given both the holistic nature of their work and the relative novelty of their positions, the majority of participants have found it difficult to develop meaningful benchmarks for measuring the success of their work: for example, in terms of increasing healthy food access or decreasing food insecurity. Despite these challenges, however, some participants continue to seek useful metrics and ways to evaluate their work.

\section{Challenges of the Position}

While participants described many benefits provided by their position, their work has its challenges, which are often unique to a particular community and staff position. Nevertheless, three general categories emerged in the analysis: (1) limited resources, (2) the scope of systemic problems, and (3) political dynamics.

Limited Resources. The most common challenges faced by participants were related to 
lack of adequate personnel and financial resources. Ironically, in their efforts to build capacity for food systems work in their communities, about half of the participants mentioned their own needs for more resources and their struggles with being the sole person working on food systems in their government. Also, three participants expressed frustration with not having a permanent or adequate budget to actually support the programs that they manage. At the time that interviews were conducted, only five of the positions represented in this study had an operational budget. Similarly, some have found it difficult to sustain programs over time due to limited resources. C. L. Graffagnino expressed a related concern: "We still have a funding system that is competitive. So, it does not encourage collaboration and people working together." Several participants noted, however, that collaboration with other departments and community organizations is crucial to making progress in their work despite resource limitations.

Scope of Systemic Problems. Several individuals described challenges related to the scale of the issues that they are tasked with addressing. For instance, reflecting upon Indianapolis's high rate of food insecurity and substantial struggle with food access, M. Kennedy explained, "when you look at the numbers ... you're constantly thinking about the kind of impact that you can make, and so, that can be a really daunting task." A couple of participants also noted the challenge of navigating the tension between short-term emergency food provisioning and longer-term, systemic food policy changes. The complex structure of food systems can also make it difficult to determine next steps or prioritize projects. When faced with the need to prioritize, the majority of participants said that their priorities are largely driven by the momentum of other projects and policies in local government as well as by salient community needs and interests.

Political Dynamics. Other challenges mentioned by interviewees centered on social and political aspects, the circumstances of which were fairly unique to their community and individual experiences. Two participants, including L. Cidlowski, food systems analyst for the city of Denver, described the inherent political frustrations that come with working in local government:

It's very political. And getting over, passed around, politics is an art, not a science... adapting to whatever the existing conditions are and understanding what will help people to change the way they've been doing things or why they should care about these food access needs. It's definitely a trickier part of it.

Similarly, Austin's food policy manager faces obstacles working in the context of a state government that has different and often opposing priorities and perspectives than the city has about governmental food systems work.

Other challenges mentioned less frequently by participants included bridging the rural-urban divide, building demand for locally produced products, and finding a balance between diving deep into specific programs and looking broadly across the whole food system. Learning to navigate politics and the many mechanics of local bureaucracy is, of course, a necessity of the job. Several participants spoke to the value in practicing patience while also being flexible enough to seize opportunities when they present themselves.

In general, food policy staff suggested that these challenges are not insurmountable and that they continue to find strategies to minimize or overcome them. Over time, individuals in these positions have been able to leverage their relationships and establish credibility, which has translated to availability of more resources and a stronger commitment by the local government to food systems work.

\section{Lessons Learned}

In addition to the perceived benefits and challenges of their position, participants were asked to share the major lessons they have learned during their tenure. Lessons were not easily generalized, particularly because some participants have been in the position for several years, while four participants had less than a year of experience in the position. Nevertheless, several common takeaways provide valuable insight for other communities.

Time and Patience. One of the most com- 
mon and, perhaps, obvious lessons participants shared was that their work takes time, and therefore requires patience. This temporal constraint is both a function of the bureaucracy and of the complex dynamics associated with food system change. For example, when new projects or policies are proposed by working groups within the $23-\mathrm{mem}$ ber Madison Food Policy Council, they must be approved by the council as a whole prior to moving up the chain of command in the city. G.

Reistad explained that the process is time-consuming, but "more often than not, the criticisms or the feedback that come through that vetting process of the food policy council has actually helped improve the idea." Ultimately, the time and dedication required suggest that it can be "its own full-time job ... something that needs undivided attention" (M. Kennedy). In learning to accept the slow pace of their work, participants have also developed strategies to maximize progress.

Adaptation to Specific Circumstances. Several participants have learned that while models from elsewhere provide valuable insights and ideas, they usually need to be adapted to the specific circumstances of their community. Three participants practice a "why not both" or "por que no los dos" philosophy: pursuing multiple strategies simultaneously in an effort to keep their options open and take advantage of opportunities when they arise. As L. Cidlowski explains:

It's good to attempt to do more than you actually can do because there may be a lot of irons you have on the back fire and you think, oh, that's not ready right now or I don't have the support for that at the current time, but something could change really quickly. A city council member could get appointed who really cares about food or a community-based coalition can get a big grant to work on community engagement.

This, again, demonstrates the significance of these individuals having an intimate knowledge of the community's food system and the various food-related activities that government departments, organizations, and community members are engaged in.
Flexibility and Continual Adjustments. Several individuals have realized that, due to the complexity of food systems and policymaking, their work does not follow a linear trajectory; rather, "it's always a squiggly line kind of path. There's never really like, 'OK, this is what we're going to do and this is how we're going to do it"' (S. Gill). In general, participants emphasized the importance of maintaining flexibility, openness, and a collaborative spirit.

Coalition Building. All participants discussed the realization that they cannot achieve anything alone and that building a network of partnerships is central to their effectiveness. A. Potter Wright explained, "relationships are paramount in this work, and I couldn't do anything without the partnerships that I've developed." Relationships are what allow food policy staff to leverage resources, make in-roads, develop lasting strategies, and achieve both leadership and community buy-ins. As a result, individuals in these positions are constantly seeking ways to network, develop champions for their work, and engage the community. Food policy staff also prioritize "engaging community members on the solutions" (J. Guffey Calkins). Similarly, four participants highlighted the significance of fostering inclusivity and making sure that all voices in the community are represented in their work, especially those most disadvantaged. For M. Kennedy, this often entails finding "not just one approach to reaching the community, but ensuring that there are a number of ways for the community to be involved, whether it's at a personal level from their smartphone or online, or in a community level by coming out and being engaged in community groups and community meetings."

Actionable Strategic Planning. An important lesson that a few participants discussed is the value of having a plan that outlines food systems goals for the community and developing strategies for implementation of the plan. For example, B. Estabrook described the local food action plan process in Franklin County and Columbus, $\mathrm{OH}$ :

A lot of times, local government creates a plan, and it sits on a shelf and no one looks at it. And everybody says, 'hey, we created this cool plan,' but there's no plan to do something with 
the plan. So, we really gave a lot of thought to: what does it look like to actually make this actionable?

Both in communities where a strategic food system plan or local food action plan exists and where it does not, food policy staff stressed the value of developing a roadmap to guide their work and help align the goals of the community with those of the local government.

\section{Recommendations for Establishing a Food Policy Position}

When asked if they would recommend that other communities develop a staff position such as theirs, seven participants affirmed that it was a valuable means of advancing a community food system. For example, K. Criner Ritchie stated, "I would say any opportunity to have a staff person that can focus on food systems work can only be a good thing," and A. Potter Wright said, "I think lots of places could benefit from a position like this." The other four participants were more reserved with their endorsement, saying that the value of these positions depends on the specific community and its available resources. From this perspective, not every city or county needs a person working in government on food systems; however, they did think that each community needs people and groups to address food systems specifically, broadly, and intentionally.

Prior to establishing such a position, several individuals strongly recommended that the city or county perform a community food assessment (CFA), such as those described by Pothukuchi (2004), to identify food systems gaps. Additionally, G. Reistad suggested doing an "asset assessment" to better understand what the community is doing well and what assets can be leveraged by a staff person to address the gaps. Three participants also suggested that the community should develop a food action plan or long-term food vision. In highlighting the value of a food action plan, two participants stressed the significance of having a full-time food policy staff position to lead the implementation of the plan.

Once a clear purpose and directives are established, four participants recommended that the community spend time carefully considering where the position should most effectively be housed in its local government, as this influences what type of work can be done. One participant, however, stressed that the specific department where the position is housed was not nearly as important as having the support of government leadership. Seven participants also identified leadership support as an essential component of successfully establishing and maintaining a position. Additionally, four participants expressed the need for financial support and, ideally, at least a small operational budget.

Overall, the 11 participants felt that having a local food policy position in government plays a valuable role for their community's food system. In general, the individuals in these staff positions expressed pride in their role in local government, citing numerous food-related achievements, and felt that their work helps to move the needle on food system reform for their communities.

\section{Discussion: Key Dimensions of Food Democracy}

The above findings provide insight into the nature of the recently established food policy positions in local government and initial evidence for understanding these positions as an approach to advancing food democracy. Accordingly, the following section analyzes these findings in light of five key dimensions of food democracy identified by Hassanein (2008), Sieveking (2019), and van de Griend et al. (2019).

\section{Collaborating Toward Food System Sustainability}

Food democracy requires effective coalitions that expand the number of people involved, include differing perspectives, and enable groups to collaboratively affect change in ways that they could not do on their own (Hassanein, 2008). Such collaborative action was clearly shown in this study in several ways. First, the genesis of these positions in local governments emerged from collaborative action among stakeholders from both in and outside government. Second, every participant in this study said that they could not achieve anything alone and/or that building collaborative networks is 
essential to their work. Third, all 11 interviewees were fundamentally concerned with developing sustainable outcomes for their community with regard to "ecological soundness, economic viability, and social justice and welfare" (Hassanein, 2008, p. 290). For example, among food policy priorities, economic development and healthy food access were the most frequently mentioned, by ten and nine participants respectively. Because collaboration is fundamental to food system sustainability and food democracy, our findings suggest that these government actors are providing leadership that facilitates such collaboration across public and private sectors in ways that are similar to findings by van de Griend et al. (2019).

\section{Becoming Knowledgeable About Food and the Food System}

Food democracy recognizes the importance of individuals having the knowledge necessary to participate effectively in the food system. We found that food policy staff often serve as a food systems expert, point-person, and educator for both the government and the community generally. Typically, as with ten of the 11 positions in this study, their responsibilities include staffing the local FPC and providing administrative support as well as expertise. FPCs likely benefit from the increased resources and expertise that food policy staff can provide while still maintaining their focus on the community's interests. Previous studies have shown, however, that an FPC's relationship with government yields complicated results. A close relationship with government can lend legitimacy and credibility to an FPC, but that relationship can also limit or undermine its efficacy by coercing it to align its work with the local administration's agenda and adhere to bureaucratic processes and timelines (Bassarab et al., 2019; Schiff, 2008). This may be true of other grassroots organizations involved with food systems work. Communities and individuals in food policy positions should take care to recognize this possibility and build strategies to elevate, not hinder, grassroots and community efforts through helping others become more knowledgeable about the food system and its elements (van de Griend et al., 2019).

\section{Sharing Ideas About the Food System with Others}

Food democracy depends on discussion and deliberation that enable community members to share their viewpoints and clarify values. Study participants indicated clearly that coordinating and facilitating such discussions across a wide variety of food initiatives in a community and across local government are central tasks in their work. While these positions are necessarily housed in a particular government department, their work encompasses a diverse spectrum of programs and policies that relate to overall community wellbeing. In the process of coordinating food-related programs and policies, food policy staff act as an effective information pipeline between a community and its government. Most importantly, in staffing the FPCs and bringing together different stakeholders, these positions have the potential to create spaces for collaboration on food system issues in ways that a strictly volunteer council may not have the capacity for.

Individuals in local food policy positions may also work to connect with others elsewhere, regionally and nationally, developing a broader network of idea sharing (Hatfield, 2012). While the U.S. Conference of Mayors Food Policy Task Force includes several people interviewed for this study, the task force is, of course, limited to municipalities. Furthermore, not all municipalities with a food policy position are included in the task force at this time. A broader network that includes both cities and counties, and perhaps national and international participants, could expand collaborative and innovative food policy initiatives.

\section{Developing Efficacy Concerning Food and the Food System}

From the outset, food policy staff positions lend increased visibility to community-driven food systems work in local government and across the community. By deliberately creating a space within government for the community to engage in food policy and programs, these positions provide an effective avenue for public participation in food system reform. Additionally, these positions represent a dedication of resources and staff time to food-related initiatives. Hassanein defines efficacy 
as "not only a capacity to act but also includes actually having an effect" (2008, p. 297). With a specific food systems point-person located in local government, individuals and communities have a clear pipeline to not only express their food-related concerns but also pursue solutions. As such, the additional resources, networks, and capacity provided by a food policy staff position may increase the efficacy of actions by citizens and food policy groups. However, it should be noted that individuals in these positions continue to face challenges with securing sufficient resources for their work and, at times, can be limited by bureaucratic processes and timelines. Practicing food democracy and developing efficacious food policy takes time and resources, both fiscal and human (van de Griend et al., 2019), and will require ongoing and collective effort by food policy staff, food-related organizations, and the community.

\section{Acquiring an Orientation Toward the Community Good}

A strong democracy requires that citizens care about the public or common good and are willing to go beyond self-interests to promote the wellbeing of the entire community. Because food is a basic human need, FPCs generally have been understood to be a space to advance the common good with respect to meeting that need (Bassarab et al., 2019; Hassanein, 2003). The extent to which a food policy staff person engages with the community FPC and seeks out the community's input varies by context as well as by the individual. While we cannot fully assess these dynamics based on this study design, clearly, in establishing these new positions, local governments are investing resources and public funding in order to promote more meaningful participation in all the dimensions of food democracy discussed above. There not only needs to be public support for creating these opportunities, but also evaluations to ensure the community feels a sense of ownership in the process and is able to participate in meaningful and effective ways (Lachapelle, 2008).

\section{Conclusion and Recommendations}

The emergence and continued expansion of FPCs demonstrates movement toward more democratic, community-based food systems. Local governments have begun to respond to pressure from community food organizations by becoming more actively engaged in food policy and increasingly dedicating staffing resources to these issues (Gupta et al., 2018; Hatfield, 2012). Our study identified ways that some local governments are using food policy staff positions to increase community capacity and move toward food democracy. However, the outcomes of such support in terms of realizing particular community food system visions needs further investigation (Raja et al., 2018; van de Griend et al., 2019).

Our study builds on the work of scholars who, over the last decade, have described the emergence of city and county governmental food policy staff positions and highlighted the potential of such positions to create food system reform (Hatfield, 2012; Raja et al., 2018; Santo et al., 2014; van de Griend et al., 2019). This study contributes to this body of scholarship by describing the purpose, functions, and outcomes of 11 food policy positions housed in city or county governments throughout the U.S. and analyzing the potential and limits of these positions to advance food democracy in their communities. As this area of research remains understudied, this study also contributes additional questions and areas for future research.

Our data show that while there are a variety of challenges for food policy staff operating in local government, many of our interviewees report significant advantages to pursuing food system reform at a governmental level. In particular, participants felt that a food policy position in local government increases the attention, resources, and coordination directed toward their community's food systems work. Our findings suggest that governmental food policy positions have the potential to support food democracy and food system reform, echoing the findings discussed by van de Griend et al. (2019) in their analysis of government actors participating in urban food policy. Therefore, we offer five recommendations for communities interested in establishing or strengthening food policy positions in local government.

\section{(1) Identify and Coordinate Existing Oppor-}


tunities and Assets. Food policy staff can expand and strengthen food-related, sustainability-focused work in their community by assessing existing opportunities, assets, and resources in the food system, which then can be leveraged to identify new prospects to address problems and resource gaps in the community.

(2) Foster and Maintain Leadership Support.

A primary step in successfully establishing and sustaining a governmental food policy staff position is securing leadership support, both from leaders in government and the greater community, by building strategic relationships, speaking to the fundamental concerns of leaders, and highlighting the key gaps and opportunities present in the food system through data and community voices. Finding champions to support systemic change through policy is critical, particularly because governmental food policy positions are a relatively new concept. Securing the support of leaders in the community can create space and resources for food policy work as well as build collaborative rapport between local government and community organizations.

(3) Root the Work in Community. At its core, the concept of food democracy is premised on the idea that all community members in a food system have valuable contributions to make in the process of developing solutions to foodrelated problems (Hassanein, 2003). Local governments interested in supporting food democracy and citizenship should strive to engage as many constituencies as possible in the decision-making process in order to successfully plan for community food systems (Raja et al., 2018). By ensuring that all community perspectives are a cornerstone of the work of food policy staff, local governments will be better equipped to understand the significant gaps in local food systems and, thus, able to build appropriate and lasting solutions.

(4) Connect with Other Food Policy Professionals. Consistent with Hatfield's (2012) recommendation, food policy staff can increase their impact by connecting and sharing resources with others in similar positions.
While a handful of resources do currently exist, food policy professionals stand to benefit from an expanded and active communication network. Rather than starting from scratch, food policy staff can learn from one another, collaborate, and amplify their work, although they may have to adapt it somewhat to their own communities.

(5) Develop a Food System Vision. A vision could take several forms, from a single vision statement to a long-term community action plan. A clearly defined food system vision that is constructed with input from the community and a diversity of food system representatives can help to guide the responsibilities and longterm goals of a food policy staff position. It may also help to ensure that the position aligns with the community's interests and values over the long term, a key consideration in advancing food democracy.

As governmental food policy positions continue to emerge, communities across the U.S. can bolster the success of their food policy work by learning from and applying lessons from the experiences of other communities, such as those highlighted in our study. Future scholarship should seek to further describe the array of existing local government staff positions in food policy, similar to the Center for a Livable Future's Food Policy Council directory. This study analyzed 11 food policy positions in an effort to describe the concept of these positions as a whole. Comparative analyses based on specific variables, such as age of the position, size of the city or county, the department in which the position is housed, and if the position supports an FPC may provide valuable insights which our analysis did not yield.

As scholars, practitioners, activists, and communities seek to nurture democratic food systems, recently established food policy positions in city and county governments offer an opportunity to connect policy and government resources with residents, local businesses, and community organizations. Such collaboration and coordination throughout a community food system may facilitate the kind of active citizenship and systemic change that is central to food democracy. 


\section{Acknowledgments}

We would like to thank all those food policy staff who graciously offered their time and perspective to this study as well as the University of Montana
Environmental Studies Program and UM BRIDGES program for their guidance and support.

\section{References}

Bassarab, K., Clark, J. K., Santo, R., \& Palmer, A. (2019). Finding our way to food democracy: Lessons from US food policy council governance. Politics and Governance, 7(4), 32-47. https://doi.org/10.17645/pag.v7i4.2092

Berglund, E. (2020). Food policy for a bealthy, sustainable, and equitable local food system: Recommendations for Missoula (Professional Paper No. 11583). University of Montana. https://scholarworks.umt.edu/etd/11583

Christensen, B., \& Phillips, R. (2017). Local food systems and community economic development through the lens of theory. Community Development, 47(5), 638-651. https://doi.org/10.1080/15575330.2016.1214609

Clancy, K. (2012). Digging deeper: Bringing a systems approach to food systems. Journal of Agriculture, Food Systems, and Community Development, 3(1), 21-23. https://doi.org/10.5304/jafscd.2012.031.017

Feenstra, G. (1997). Local systems and sustainable communities. American Journal of Alternative Agriculture, 12(1), 28-35. https://doi.org/10.1017/S0889189300007165

Gupta, C., Campbell, D., Munden-Dixon, K., Sowerwine, J., Capps, S., Feenstra, G., \& Van Soelen Kim, J. (2018). Food policy councils and local governments: Creating effective collaboration for food systems change. Journal of Agriculture, Food Systems, and Community Development, 8(Suppl. 2), 11-28. https://doi.org/10.5304/jafscd.2018.08B.006

Harper, A., Shattuck, A., Holt-Gimenez, Alkon, A., \& Lambrick, F. (2009). Food policy councils: Lessons learned (Development Report No. 21, executive summary). Food First. https:// foodfirst.org/publication/food-policy-councils-lessons-learned/

Hassanein, N. (2003). Practicing food democracy: A pragmatic politics of transformation. Journal of Rural Studies, 19(1), 77-86. https://doi.org/10.1016/S0743-0167(02)00041-4

Hassanein, N. (2008). Locating food democracy: Theoretical and practical ingredients. Journal of Hunger \& Environmental Nutrition, 3(2-3), 286-308. https://doi.org/10.1080/19320240802244215

Hatfield, M. M. (2012). City food policy and programs: Lessons harvested from an emerging field. City of Portland, Oregon Bureau of Planning and Sustainability. https://www-static.bouldercolorado.gov/docs/City-Food-Policy-Programs-web1-1-201304101132.pdf

Hendrickson, M., Howard, Philip. H., \& Douglas, C. (2017). Power, food and agriculture: Implications for farmers, consumers and communities (Working paper). University of Missouri, College of Agriculture, Food \& Natural Resources. https://doi.org/10.2139/ssrn.3066005

Hesse-Biber, S. N. (2017). The practice of qualitative research (3rd ed.). Sage Publications.

Johns Hopkins Center for a Livable Future. (n.d.). Food policy groups around the world. Johns Hopkins Bloomberg School of Public Health, Johns Hopkins Center for a Livable Future. http://www.foodpolicynetworks.org/fpc-map/FPC-around-the-world.html

Lachapelle, P. (2008). A sense of ownership in community development: Understanding the potential for participation in community planning efforts. Community Development, 39(2), 52-59. https://doi.org/10.1080/15575330809489730

Lamie, R. D., \& Deller, S. (2017). Motivations for a special issue on local food systems. Community Development, 48(5), 609-611. https://doi.org/10.1080/15575330.2017.1373899

Lang, T., Barling, D., \& Caraher, M. (2009). Food Policy: Integrating bealth, environment and society. Oxford University Press, Oxford Scholarship Online. https://doi.org/10.1093/acprof:oso/9780198567882.001.0001

Muller, M., Tagtow, A., Roberts, S. L., \& MacDougall, E. (2009). Aligning food systems policies to advance public health. Journal of Hunger \& Environmental Nutrition, 4(3-4), 225-240. https://doi.org/10.1080/19320240903321193

Palmer, A., \& Santo, R. (2020). Building the foundation to grow food policy: The development of a toolkit to measure advocacy capacity. In A. Blay-Palmer, D. Conaré, K. Meter, A. Di Battista, \& C. Johnston (Eds.), Sustainable food system assessment: Lessons from global practice (pp. 159-177). Routledge. 
Pothukuchi, K., \& Kaufman, J. L. (1999) Placing the food system on the urban agenda: The role of municipal institutions in food systems planning. Agriculture and Human V alues, 16(2), 213-224. https://doi.org/10.1023/A:1007558805953

Pothukuchi, K. (2004). Community food assessment: A first step in planning for community food security. Journal of Planning Education and Research, 23(4), 356-377. https://doi.org/10.1177/0739456X04264908

Raja, S., Clark, J. K., Freedgood, J., \& Hodgson, K. (2018). Reflexive and inclusive: Reimagining local government engagement in food systems. Journal of Agriculture, Food Systems, and Community Development, 8(Suppl. 2), 1-10. https://doi.org/10.5304/jafscd.2018.08B.013

Santo, R., Misiaszek, C., Bassarab, K., Harris, D., \& Palmer, A. (2021). Pivoting policy, programs, and partnerships: Food policy councils' response to the crises of 2020 (Report). Johns Hopkins Bloomberg School of Public Health, Johns Hopkins Center for a Livable Future. https://assets.jhsph.edu/clf/mod clfResource/doc/FPC\%202020\%20Census\%20Report 2021-04-05 FINAL.pdf

Santo, R., Yong, R., \& Palmer, A. (2014). Collaboration meets opportunity: The Baltimore Food Policy Initiative. Journal of Agriculture, Food Systems, and Community Development, 4(3), 193-208. https://doi.org/10.5304/jafscd.2014.043.012

Scherb, A., Palmer, A., Frattaroli, S., \& Pollack, K. (2012). Exploring food system policy: A survey of food policy councils in the United States. Journal of Agriculture, Food Systems, and Community Development, 2(4), 3-14. https://doi.org/10.5304/jafscd.2012.024.007

Schiff, R. (2008) The role of food policy councils in developing sustainable food systems. Journal of Hunger \& Environmental Nutrition, 3(2-3), 206-222. https://doi.org/10.1080/19320240802244017

Sieveking, A. (2019). Food policy councils as loci for practising food democracy? Insights from the case of Oldenburg, Germany. Politics and Governance, 7(4), 48-58. https://doi.org/10.17645/pag.v7i4.2081

United States Conference of Mayors. (n.d.). Committees and task forces. https://www.usmayors.org/the-conference/committees-and-task-forces/

van de Griend, J., Duncan, J., \& Wiskerke, J. (2019). How civil servants frame participation: Balancing municipal responsibility with citizen initiative in Ede's food policy. Politics and Governance, 7(4), 59-67. https://doi.org/10.17645/pag.v7i4.2078 


\section{Appendix. Interview Guide for Municipal or County Food Policy Positions}

Introduction: Before we get started, I want to thank you for giving your time and agreeing to participate in this interview-I am excited to have the opportunity to connect with you.

I also want to thank you for completing the informed consent form.

\section{Begin Interview:}

Personal background: I'd like to start with a little bit about your background and the basics of your position.

1. How long have you held the food policy (manager/director/coordinator) position for (city or county name)?

Follow-up: are you the first to hold this position?

2. Briefly, what educational and/or experiential background do you bring to the job?

Probe: what is your experience working on food-related policy?

3. What are some of your main job responsibilities?

4. I understand that your community has a food policy council, what relationship does your position have with the council?

Probe: How has the council's work changed, if at all, since your position was created?

Structure/organization of position: Great, now l'd like to learn about the genesis of the position itself and the local government's work on food policy.

5. What department of government is the position housed in?

Follow-up: who is your direct supervisor?

6. How is the position funded?

7. Why did the (city/county) create this position?

Follow-up (if necessary): when was that?

Follow-up: what steps were taken to establish the position?

Probe: are there any other the reasons?

8. The term "food policy" encompasses a wide variety of food-related dimensions, what aspects of food policy does you prioritize in your position?

Probe: How do you go about setting those priorities?

9. How is progress on food-related goals measured and evaluated?

Lessons learned from position: Now that I understand the context of the position, l'd like to hear more about your personal experiences working as the (food policy manager/coordinator/etc.).

10. What do you see as the primary benefits of this position for the (city/county)?

Probe: are there any other benefits you'd like to mention?

11. What are some notable accomplishments that you have led in this position?

Probe: any others? 
12. What are some of the major challenges that you face in this position?

Probe: any other challenges?

Probe: how are you meeting those challenges?

13. What major lessons have you learned from this position?

Probe: What changes, if any, would you make to the organization or responsibilities of the position?

Wrap-up/big picture: Now, I just have a few more questions to wrap up our conversation.

14. Would you recommend that other communities develop a food policy coordinator position? Why or why not?

Follow-up: if so, are there any key ingredients they may need for success?

15. Is there anything else you think I should know but we didn't touch on?

16. Do you have any questions for me?

Again, thank you so much for your participation. I've really enjoyed speaking with you. Is it OK if I circle back to you if I have any additional or clarifying questions?

\section{End Interview.}

* Note: If unable to find job description online, be sure to request one from interviewee * 